\title{
Aldus and Greek Learning
}

\author{
H. George Fletcher ${ }^{\dagger}$
}

For all its narrow specialization, my topic has broad implications, treating a crucial period in the history of the transmission of learning in the West, one rich in dominant personalities, major geopolitical developments, and intellectual and cultural movements that would begin to change the face of society and ultimately produce the world we have inherited. Aldus with his achievements was at the heart of some of the significant parts of these changes; perhaps more importantly, however, he was perceived by the learned world of his time as a, or perhaps even the, focal point. ${ }^{\mathrm{I}}$

Two areas concern us: first, the Renaissance and its guiding principle, humanism; second, the origins of printing from movable type in the West, and its migration across the Alps to Italy and then specifically to Venice. The broad canvas on which we view Aldus, his successes and failures, consists of Italy, the Renaissance, humanism, and the revival of classical learning in the West - in particular the reacquisition and dissemination of the works of Greek antiquity in their original texts.

For our purposes, the Italian Reniassance may be summed up in the concept of humanism. ${ }^{2}$ Humanism involves scholarship applied to works of literature, the transmission of literature, the cultivation of a literary hand with by extension the writing of manuscripts of fair text, and, finally, printed books. It also involves holding human affairs at the centre of one's activities, of being concerned with the things of this world, of taking human nature for the core around which all one's constructs are drawn. It developed out of the rediscovery of the Graeco-Roman world, especially Greek literature and philosophy. (Let us note, too, if only as an aside, that humanism would lead shortly to a scientific revolution: the wider sense of critical inquiry, whereby textual criticism led, in part, to the conviction

$+\mathrm{H}$. George Fletcher is the Astor Curator of Printed Books and Bindings at the Pierpont Morgan Library in New York City. 
that a human being could use human senses to investigate the corporeal world.)

The origins of humanism may be found in Padua in the second half of the thirteenth century, in the circle of Lovato Lovati /I24II 309|, a judge devoted to the literature of antiquity, especially poetry. Humanism's two strands, literary and scholarly, were first united by Petrarch (1304-1 374). His vision and influence spanned Western Europe, or what tended to think of itself as Western Christendom, and Petrarch sought to revive the ideals of the ancient world within the framework of Christian Europe. He is the bridge that makes possible Europe's transmission from the Middle Ages to the Renaissance. He found in the works of Cicero and Varro a means to define educational ideals. ${ }^{3}$

Humanistic scholarship addressed primarily the matter of restoring classical texts; this scholarship was further developed in restoring Scripture to its original form and in its original languages, and, by extension, patristics. This latter area would become a specialty in Basel, where it would be very important for Amerbach and for Froben and the Erasmian circle, in the years that followed Aldus's death.

Reynolds and Wilson in their excellent Scribes and Scholars summarize the period thusly:
A cultural movement which is recognizable as humanism, the stimulating force of the Renaissance, was at work in certain parts of Italy by the end of the thirteenth century; by the middle of the sixteenth it had spread to most of Western Europe and had trans- formed, among so many other things, the transmission and study of classical antiquity. The scholar of the late Renaissance had at his disposal almost as much of the literature of Greece and Rome as we possess ourselves; most of it he could read, at ease and at no great cost, in print; and the translation of Greek into Latin, and of both into the vernacular languages, had made a large part of ancient literature available to the public at large. On the scholarly side, the founda- tions of historical and textual criticism had been securely laid. 4

This succinct statement takes us well beyond my topic, how 'the scholar of the late Renaissance had at his disposal almost as much of the literature of Greece and Rome as we possess ourselves.' Apart from the 'no great cost' element, which I would dispute vigorously, I find this an admirable summary. Let us consider this background further. 
My topic, of course, is Greek learning. Parallel to the Latin situation, we may also here designate two persons as equally pivotal to crucial developments. The revival of Greek may in a real sense be attributed, if perhaps rashly and even imprudently, to one man in the fourteenth and one in the fifteenth century. The former is Chrysoloras, and the latter, Bessarion. Manuel Chrysoloras (ca. I 355-I4I 5/ was a Byzantine diplomat who began to lecture publicly on Greek at Florence in 1397, the first time Greek literature was taught in Italy in modern times; one of his pupils was Guarino, who would become Aldus's intellectual grandfather. During preparations for the Council of Florence and Ferrara, Bessarion(I403-I472), Bishop of Nicaea and in his mid-thirties, made the acquaintance of his Western contemporary Nicholas of Cusa, in I437, at Constantinople. He and Cusanus traveled to Italy and notably to Venice, and they developed an important friendship. Their mutual interests in Church reform and unification and in Greek literature and philosophy bore notable fruit. Bessarion went on to become both a rallying point and a sticking point within the Church, and nearly became Pope, but that is not our concern. What is our concern is that he brought into being a major library - in manuscript - of Greek works, which he eventually donated to the Republic of Venice, in I468. The manuscripts are still there, and represent a trove of works that stand as a permanent monument to the man who had done more than anyone else to preserve them..$^{5}$ They were known as part of, and served as an important symbol of, the revival of Greek letters.

But they were truly symbolic: the Serenissima, conscious of their significance and great value, kept the manuscripts locked away for centuries. They were not available for use or even casual consultation, and we merely assume that Aldus, along with a few of his contemporaries, knew that they existed, and also knew that they were inaccessible. ${ }^{6}$ In an odd way, Bessarion's manuscripts served as guarantors of the value of Aldus's work and ideals: their great value and treasured inaccessibility proclaimed the importance of Greek literature and its desirability, and did so here in the no-nonsense, all-important Venetian arena of finance.

Printing from movable metal type in the West begins, of course, at Mainz on the central Rhine by about I 455 , the galvanic invention of the genius known as Johann Gutenberg. When printing moved south of the Alps a decade later, it met and joined forces with humanism in Italy. Supply and demand came together to spread Renaissance ideals. Italy rapidly came to the forefront in printing, 
and Venice, the great commercial center linking East and West, North and South, dominated the craft in Italy. Between I469 and the end of the century, it is calculated, half the books printed in all of Italy issued from Venetian shops. ${ }^{7}$ Aldus would move to Venice to join this campaign in 1490 , a quarter-century after, and would begin to issue books just thirty years after, printing began in Italy. ${ }^{8}$

Printing came to Italy with Conrad Sweynheym and Arnold Pannartz, both clerics in minor orders, with ties to the diocese of Mainz. 9 They also had ties directly into the first printing establishment, that of Gutenberg, Fust, and Schoeffer. They saw no domestic future in their new craft following the Sack of Mainz in I462, and they sought, like Goethe and countless other Germans after them, an early spring in Italy. They began in 1465 , first in the Benedictine monastery at Subiaco in the hills outside Rome, and then in Rome itself, between I 468 and I47I, where they established their shop in the Massimi palazzo. Their first surviving book is an edition of Cicero De oratore. It is significant as the first extant book printed in Italy (its sole predecessor was a grammar known only from records, since not even a fragment survives); it is significant, too, as the work of a classical author, rather than a religious work.

Printing at Venice began in 1469 , and was dominated for its first decade, the ' 70 , by a French printer, Nicolas Jenson, who may also have had direct ties to Gutenberg, or at least with his original shop. He shared Gutenberg's trade of goldsmith. ${ }^{10}$ Jenson died shortly after composing his last will on 8 September 1480 , and an associate of his successor firm was an Italian from Venetian territory in Lombardy named Andrea Torresani, of Asola. Torresani's books were both predictable - safe works that earned sales and incurred no official wrath - and lucrative. They were normally rather bland physically, but it happens that the finest single copy of anything he produced is in my keeping. ${ }^{\text {II }}$

In 1483 Torresani cooperated with another Venetian printer to issue a full-scale Latin translation of Aristotle's works, and one copy on vellum was specially decorated by the leading miniaturist of the day - Girolamo da Cremona - to present to the leading German merchant Peter Ugelheimer, from Frankfurt am Main, who was the landlord of the Fondaco de' Tedeschi, at the Rialto Bridge. He had backed this venture, as well as much else in the Venetian publishing world. ${ }^{12}$

We meet in Torresani an important and practical contact for Aldus, in the years before the Aldine Press began to function, a man who had survived in the rough-and-tumble world of Venetian 
publishing since its early days. Printing had achieved both successes and failures in Italy by the ${ }^{1490}$; in Venice itself there had been a wholesale collapse of the trade as early as the I470s, and Torresani became a printer in the milieu that arose as this disaster sorted itself out. Andrea Torresani was Aldus's contemporary, held Venetian citizenship, and evolved his own business out of Jenson's firm. Yes, everyone does seem to have known everyone else. Within ten years, Torresani would make the acquaintance of our newcomer to this world, Aldus Manutius.

Aldus Manutius was born in Bassiano, an insignificant Latian hill-town some sixty-five kilometers southeast of Rome, in about I452. He remained throughout his life a native Roman citizen. Although his forebears seem to have been resident at Bassiano in the Monti Lepini since the fourteenth century, his origins are completely obscure. His scholarship was formed as a student of Domizio Calderini and Gaspare da Verona at Rome, from whom he learned Latin letters, and then of Battista Guarino at Ferrara. Battista was son and successor of Guarino, whom we met as a pupil of Chrysoloras's, when Greek studies began in Italy.

Battista taught Aldus Greek, and it was also at Ferrara in the 1470 s that Aldus met Manuel Atramyttenos, from Crete, who was the first of a group of Greek émigrés who formed Aldus's inner scholarly circle of scribes and scholars. Over the years they would include Aristoboulos Apostoles, Justin Decadyas, Demetrios Ducas, and (most importantly) Marcus Musurus, as well as Immanuel Rhusotas, whose scribal hand may have been Aldus's model for his first Greek font.

From about 1483 , after he had come under the influence of Pico della Mirandola, he was the tutor of Pico's nephews, the Pio di Savoia princes of Carpi, Alberto and Leonello, whom he taught Latin and Greek. He continued in this role for some half-dozen years.

Aldus wrote that he moved to Venice, in about the summer of I490, to undertake a new career that he had envisioned: the selfimposed task of making available in print the works of classical Greece not yet published in their original language. This was, may we say, an heroic enterprise. He chose Venice because it was the great commercial center and home to the greatest concentration of printers the world had yet experienced. Like all Venetian goods and products, whether home-grown in, or imports in transit through, the Venetian dominions, books moved quickly along the established Venetian trade routes, over water and land, beyond natural 
and political boundaries, with commendable speed and efficiency. We know that especially the books found their way across the Alpine barriers, into the lands of the Empire and beyond, with a frequency and speed that rival today's delivery times.

Aldus made the acquaintance of Torresani by early I 493 . Within a year or two, Aldus would persuade Torrresani to undertake a new and very expensive printing office that would bear Aldus's name (in English, the Aldine Press), and would begin to publish books in the spring of 1495 . A silent partner would provide at least half the capital, Pier Francesco Barbarigo, son and nephew of Doges of Venice.

The sole efficient way to disseminate knowledge was through the relatively new art of printing. Venice was also important to Aldus as the home in exile of a large population of Greek émigré scholars - both the Byzantines driven from Constantinople by the Turks in 1453 and free Greeks from Crete and the islands in Venice's Mediterranean dominions. By the time Aldus first enters upon the world stage of printing, the craft is mature and vigorous, if with an already checkered career of successes and failures. It is now some thirty-five years since Gutenberg's mixed success in Mainz, and twenty-five since Sweynheym and Pannartz had brought the craft to Italy. They were very productive workers, both at Subiaco from 1465 , and especially in Rome, where they issued a prodigious number of editions between 1468 and $147 \mathrm{I}$. In the absence of other candidates and in the light of his interests and activities, one could conclude that the man who brought them to Subiaco was none other than Nicholas of Cusa. ${ }^{13}$

The first book printed in Italy with a date is the edition of Lactantius's works finished by Sweynheym and Pannartz at Subiaco on 29 October 1465 . It is very important to us as another milestone: it contains the first appearance in Italy of Greek typography. The roman font, which is intended to be appropriate for reading the secular classics, is a notable departure from Gutenberg's liturgical splendor. (But we should note, however briefly, that it is not at all notably different from Fust and Schoeffer's revolutionary I 462 font for the 48-line Bible.) A northern ductus in the font, though, clearly reflects its origins, and contrasts noticeably with Jenson's first roman font.

The Subiaco prototype Greek is based upon the cursive hand, and the font, though effectively lacking breathings and accents, is already sophisticated. Moreover, it occurs in the same year as a Cicero printed at Mainz by Schoeffer for Fust, the first setting of 
Greek anywhere. (Can all this be merely circumstantial? I hardly think so.) So here we have evidence of the influence of the Renaissance in Italy at this early date in the history of printing below the Alps, and in this guise it apparently is, like printing itself, a German export.

The need for Greek typography is thus immediately apparent, but its production is a very complicated enterprise. While it would be gratifying to find Aldus and his Greek works arising from the sea of previous activity as a new practitioner of a new craft, there were, of course, others before him of like mind to some degree. Aldus was a principal of the I34th firm to take up printing in Venice alone. What satisfied, to some degree at least, the market for Greek texts was, of course, a goodly supply of translations, in the universal language of the literate, Latin. There is, for example, the Latin edition of Aristotle, De natura animalium, printed at Venice in I 476 by Johannes de Colonia and Johannes Manthen. As German émigrés, they fit the predominant pattern of the early printers at Venice, the all-important Frenchman Nicolas Jenson being the exception, but then they also formed components of one of Jenson's consortia. We could expand the examples almost endlessly, but our concern is with Greek itself.

By the time Aldus began to issue books, there were or had been many other printing locales throughout the peninsula. A very few shops, mostly in Milan and Florence, though including Venice, undertook to produce books in Greek. One of the German printers at Venice in the very early days published, about I $47 \mathrm{I}$, the first book that set out to be a major Greek undertaking. This was the first printed edition of Manuel Chrysoloras's grammar, the Erotemata (or 'Questions'), issued by Adam de Ambergau without date. It was not satisfactory because of the lack of an adequate, extensive Greek font; indeed, all the typography, in both Greek and Latin, has a rudimentary aspect to it. The first wholly Greek edition of Chrysoloras's grammar, and thus the first wholly Greek book, appeared in Milan in I476; the unique known survivor is preserved in the Riccardiana in Florence.

Because of technical abilities and scholarly means, Milan and Florence in fact led the way in the publication of Greek. It might be reasonable to expect that Florence would have been at the heart of Greek printing, since it laid strong claim to being the home of humanism, it was the home of many Greek émigrés, especially following the fall of Constantinople to the Turks in 1453, and it was also the home of a successful local printing industry. This did 
not happen, possibly in no small degree because of the political situation in Florence, and at least partially because the dominant Greek scholarly community was in Venice; but Florence led the way with what is arguably the most significant printed Greek literary work in the incunabular period.

The roughly dozen books printed in Greek before Aldus consisted mostly of grammatical works. The very few literary texts were limited to Homer, Isocrates, Aesop, and the Greek Anthology, as well as parts of Hesiod, Theocritus, Euripides, and Callimachus. Florence produced what is widely acclaimed as the greatest of the incunabular literary editiones principes, that of Homer. It is the foremost witness to the rise of humanist scholarship in Florence, and the first printed edition of the major work of Greek classical literature. It was printed by Demetrius Damilas \& Bartolommeo di Libri for Bernardo and Nerio Nerlio, after I 3 January I488/9, and it was edited by Demetrius Chalcondyles. Chalcondyles (I 424-I 5 I I) was the earliest of the Byzantine editors, and he lectured at Florence for the score of years I47I-I49I; his edition of Homer is his greatest achievement. (Incidentally, he is depicted among the humanists by Ghirlandaio around 1490 in the artist's frescoes in Santa Maria Novella.)

When Aldus's publishing adventure began to issue books by middecade, Aldus was in his early forties, a private teacher or tutor by profession, a Roman who sought from and was granted denization by the Venetian Republic. Aldus continued as a teacher, though applying his energies in new technological directions. He became, not a professional printer, so much as a printing professional: a person who earned his living solely through working in a printing establishment - one, moreover, which was known under his name, even though he was a minor partner. In our terminology, we would properly think of him as a combination editor, proofreader, and publisher. Aldus functioned intensely and probably happily as an editor who was heavily involved in daily operations, working in close proximity to the noisy pressroom. He became very involved over the years especially in the technology of typefounding, and his concern for rendering Greek in type was all-consuming. I assume that, on a path that mirrored some of Gutenberg's career, Aldus spent his first few Venetian years in technical experiments.

Greek typefonts are of their nature complex and multi-faceted. They must contain both capital and small letters in various sizes, which must work harmoniously, and breathings and accents. The metal types must reflect the literary hands that readers of 
Greek can understand, and Greek handwriting never underwent the kinds of scribal reforms that caused Latin hands to develop very differently throughout the Middle Ages. ${ }^{\mathrm{I}}{ }^{4}$ Greek scribal practice produced very complex usages, repleat with ligatures, contractions, and abbreviations. This was feasible for the flexible quill, and the cursive minuscule hand thus consisted of far more than the individual letters, embracing as well composite forms and elaborate but non-essential linking elements.

This became terribly intricate for the typefounders. Among the antecedents to Aldus's efforts, two works produced at Venice in Greek by Laonicus and Alexander comprised, according to Proctor, some $\mathbf{I} 300$ sorts, including accents and breathings. ${ }^{15}$ Nicolas Barker has observed that the predecessor fonts to the Aldine Greeks numbered some 1350 sorts. ${ }^{\mathrm{I}}{ }^{6} \mathrm{My}$ distant predecessor at the Library I have the honour to serve, Curt F. Bühler, observed over forty years ago that Aldus's Greek fonts each tallied well upwards of a thousand sorts, in order to produce the scribal variants and ligatures. ${ }^{17}$ This contrasts during recent generations of letterpress printing in Greek with approximately 200 sorts, and gives a quick idea of the complexity of Aldus's technical achievement. The high figure of more than a thousand sorts has been decried by, among others, Paul Needham, ${ }^{18}$ my immediate predecessor, who holds for a tally in excess of 300 and Martin Davies, who reports 330 sorts in the first or Aristotle font. ${ }^{19}$ Current charts of the Greek fonts may be seen in the second edition of Nicolas Barker's Aldus Manutius and the Development of Greek Script et Type. ${ }^{20}$

The contention between the disputing parties goes to the very nature and style of the Aldine Greek fonts, and their relative legibility. The basic issue is the contrast between the majuscule and the minuscule alphabets, their conversion to metal type as upperand lower-case sorts respectively, especially as this engages the lapidary or inscriptional qualities of the capitals and the cursive tendencies of the small letters, as well as the exacerbation of scribal elisions, contractions, and combinations.

The year before the Aldine Press began to issue books, Aldus's subsequent friend and sometime collaborator Janus Lascaris edited the Greek Anthology (the Planudean Anthology, as it is also known). It was completed at Florence by Lorenzo di Francesco di Alopa on I I August I494, and Lascaris explains in his dedicatory letter to Piero de' Medici the technical difficulties of producing Greek type. Di Alopa set the book in his innovative all-upper-case font, which combines what more recent typography calls caps and 
small caps, to produce an all-caps effect. It is based on inscriptional models, and di Alopa deemed it more legible than cursive. The style mimics, after a fashion, most Greek manuscripts before the ninth century, which were written in (uncial) capitals. But di Alopa was wrong: the printing innovation did not satisfy the market, and di Alopa was driven to produce a cursive font within two years.

Cursive Greek was the scribal fashion, it was the norm that Greeks and Western scholars deemed more commonly appropriate for reading than the lapidary capitals, and it was the style that Aldus embraced. ${ }^{21}$ 'Byzantine' as an English adjective /one tending toward the mildly pejorative) describes the complex and intricate; the Byzantine element in Greek scribal usage is so dominant in this sense that one has to know what one is reading in order to be able to read it with any facility.

Aldus effectively patented his technical achievement with the Serenissima, gaining protection within Venetian dominions for many years. He certainly did not have to contend with the kind of counterfeiting and theft of property that plagued his italic typeface and the portable library, but then the competition was not up to the technological level that would have enabled them to copy the fruits of Aldus's labour. Moreover, another side of this issue may be seen in the cooperative rather than competitive relationship between the Aldine Press and the all-Greek venture of the Callierges and Vlastos partners. Aldus stocked their works and offered their huge grammatical publications in his own catalogues, and the two firms issued complementary works and even editions.

What Aldus achieved - and this must have been a large part of his efforts in the start-up period between the summer of 1490 and the beginning of 1495 - fell into two general areas. The first was the creation of a large variety of complex type sorts that captured ligatures, abbreviations, and other similar scribal conventions in hard metal. The second - which was by far the greater technical achievement - was the perfecting of a means of fitting various components together into one type sort. They united all the possible combinations of accents and breathings into the same piece of type that embraced the letter itself. It seems to have been achieved by 'drifting' (if I may use that term) the diacritical elements over the letter, by the use of one or more matrices, with special spacers, to have the assemblage ready for the typefounder to cast in lead into one piece.

Three illustrations in Nicolas Barker's Aldus and Greek are wonderfully detailed enlargements from copies of Lascaris and 
Bolzani in the British Library. ${ }^{22}$ We should note particularly how the furniture has worked up, and how the inking has preserved evidence of the framework and the extra lead unintentionally cast.

Mr. Barker has been courageous enough to assign a definite source to each of Aldus's four Greek fonts. The first font is modeled on the hand of Immanuel Rhusotas; the second, again on Rhusotas's, perhaps with admixtures from John Gregoropoulos; the third, on Marcus Musurus's, also perhaps with Gregoropoulos influence; and the fourth on Aldus's own Greek script. I am not fully convinced of all these attributions, but that is my problem, not Mr. Barker's. Several wise critics have offered at least partial support for Mr. Barker's conclusions. The greatest problem is that the Aldine hotmetal typefonts - rigid (indeed, inert) punches, matrices, and type sorts - seek to capture the creative fluidity of the living scribal hands. They can do so only within certain physical limits, and the eye of the critic must conclude at many points by something of a leap of faith that there is a direct linkage between source and type. I give Mr. Barker the benefit of the doubt; in the case of the fourth font, at least, I believe that he is correct.

The Cracherode copy of Sophocles in the British Library, which contains variants that do not occur in at least two other copies that I have checked, is composed in the fourth font, and Mr. Barker reproduces a particular detail. ${ }^{23}$ It is a marvel of precision, particularly when we envisage the minute scale of the original, and thereby appreciate the typecutter's triumphant achievement. (The maximum trim size of the page of paper on which the page of type rests is approximately 160 by 100 millimeters, and those measurements allow for very ample margins.)

What Aldus intended to achieve in Greek is well chronicled in his books, when he often talks about his programme. Aldus set forth his editorial and publishing programme from the beginning, reinforced it over the years, and was successful to a remarkable degree in carrying out his announced plans. His topical prefaces or dedicatory letters are a mine of information. His prize pupil had been Alberto Pio di Savoia, Prince of Carpi, whom he had tutored in the I480s, who may have provided financial support either privately to Aldus or to the Press, and to whom Aldus dedicated all of what he terms his 'philosophy' titles from I495 to I5 I 5 - that is, from first to last. The first was Aristotle and the last was Lucretius, and most of them were Greek.

In the first volume of the monumental Aristotle, that containing the works on Logic, known as the Organon, of I November 1495, 
Aldus tells Alberto Pio what he is about. He promises to print all the Greek classics, a programme that he has now inaugurated with this volume, which he and Alessandro Bondini have edited. He will rescue from destruction and ruin the great literary monuments of antiquity. He is doing all this so that scholars may become proficient in bonis litteris, that is, in the classics. He had already stated these goals in issuing Lascaris's grammar, the Erotemata, in March I495, the first book and the first dated book from the Press. Aldus told his readers in three prefaces what he had in mind. First, he was producing this grammar as an inaugural publication that would teach the language to youth and serve as a prelude to his publishing the Greek authors, and he was adding his own Latin translation to make it more accessible. Second, he was including familiar prayers in Greek, like the opening of St. John's Gospel and the Nicene Creed, as an aid to youthful readers or to their teachers, plus other useful works. Third, young students would perform a double good by using the Lascaris: they would learn Greek, and they would encourage Aldus to continue his publishing programme.

When he resumed the edition of Aristotle - the four cohesive volumes of the balance of the known Aristotelian corpus with allied works by Theophrastus and others, published in 1497 and I498 he addressed Alberto Pio again. In February I497, he begins the volume containing Aristotle's Physics and Theophrastus by dedicating the volume to Alberto Pio, mourning the death of Alberto's uncle Pico, and praising the scholarship of the English physician Thomas Linacre. He has included Theophrastus because it complements Aristotle by treating topics not dealt with by him, but he deplores the scarcity of manuscripts of Theophrastus. He had found only one in all of Italy. He promises to print the remaining works of Aristotle and Theophrastus, as well as the complete works of Plato, Hippocrates, and Galen, plus other major Greek medical and mathematical writers.

This volume also contains the first mention of the so-called Aldine Academy. The Neakademia is something of a loaded question if not a red herring. In my opinion, it was a fairly loose social and working assemblage of Aldus's friends, editors, and colleagues, from near and far, who were like-minded in their interests and pursuits. A few recent writers have taken to referring to the Neakademia as a dining club, and I think that this is an accurate depiction of its structure. Occasionally their interests and pursuits brought the members together, and they were responsible in varying ways for such successes as the editiones principes of Demosthenes and 
Sophocles. The Academy existed in a real sense while Aldus worked from the house on the square at Sant'Agostino (ca. February I496December I505/, and it shows up in some talk about Aldus's possibly moving to Germany and accepting an imperial appointment; but as late as his second Ferrarese will of 24 August I 5 I I he still speaks of hoping, one day with God's help, to establish the Academy. ${ }^{24}$ Let us simply note the significance for our topic that even the concept of the Aldine Academy carries: a re-creation in Venice of the methods and purposes of the Stoa, using the learned tongue Greek for all discussions, preparing and publishing editions of the works of the classical Greek authors.

Periodically, Aldus issued a kind of progress report on what he was achieving, and how he was proceeding toward his goals. In the Origen, of February I 503, we find a promotional passage in the preface to the reader lauding the work of Andrea Torresani and Aldus in their typographic adventure, crediting Andrea with backing the enterprise and Aldus with the scholarly control that made it worthwhile. To bring this about, Aldus is described (in the third person) as adjudicating not just works and sentences but individual syllables; by deleting some and clarifying others, he ensured that the final text need fear no critique.

Between I47I (or I476 if we count only from the completely Greek version of Chrysoloras's grammar) and 1495 - that is, in any event, from the Italian beginnings until Aldus commenced work - only about a dozen books had been printed in Greek in all of Italy, comprising grammars (at the low end of the scale) and very few literary texts (at the high end). But Aldus would achieve a remarkable body of work in Greek within a total span of a score of years, 1495 to 1515 , a period also marked by substantial interruptions of about four years in total. He produced some thirty-one editiones principes in thirty-eight volumes, the most notable including Aristotle, Aristophanes, Thucydides, Sophocles, Euripides, Demosthenes, Plutarch, Pindar, and Plato. Most of these were folios, in Aldus's unique trim size for the format, but Sophocles, Euripides, and Pindar were produced in the new small format. And the Pindar was set in a large font but imposed in the octavo format, an amalgam resulting in a most handsome and striking design.

The experts have never entirely agreed on precisely which and how many of the Greek editiones principes Aldus published, but the disagreements have often been the result of interpretation rather than outright rejection of rival claims. The low number, let me repeat, is thirty-one works in thirty-eight volumes, and the high 
number is three times that count. The difference is explained, if not explained away, by counting each minor author's individual work contained in some of the collected volumes, and by including Byzantine authors as well as the classical ones.

Let us venture an accounting of the stewardship. The basic list, in any event, has not changed for many decades. ${ }^{25}$ The authors are

$\begin{array}{ll}\text { I495 } & \text { Musaeus } \\ \text { I495(-98) } & \text { Aristotle } \\ & \text { Theophrastus } \\ \text { I496 } & \text { Theocritus, Bion, Moschus, Hesiod, Theognis } \\ & \text { Scriptores grammatici } \\ \text { I498 } & \text { Aristophanes } \\ \text { I499 } & \text { Astronomici veteres } \\ & \text { Epistolographi graeci } \\ \text { I502 } & \text { Stephanus Byzantinus } \\ & \text { Pollux } \\ & \text { Thucydides } \\ & \text { Sophocles } \\ & \text { Herodotus } \\ \text { I 503 } & \text { Euripides } \\ & \text { Ammonius Hermiae } \\ & \text { Ulpian \& Harpocration } \\ & \text { Xenophon, Hellenica } \\ \text { I 504 } & \text { Philostratus } \\ & \text { Philoponus } \\ & \text { Demosthenes } \\ \text { I 508-I 509 } & \text { Rhetores graeci, including Aristotle, Rhetorica } \\ \text { I509 } & \text { Plutarch } \\ & \text { Oratores graeci } \\ \text { I513 } & \text { Pindar } \\ & \text { Plato } \\ \text { I514 } & \text { Alexander Aphrodisias } \\ & \text { Athenaeus } \\ & \text { Hesychius. } \\ & \end{array}$

Those keeping count will have passed thirty-one, even allowing only one author for the collective volumes. But it is difficult to concentrate on mere counting when the mind is distracted by the 
wealth of materials, learning, and sheer dogged persistence that produced a body of work of this magnitude and importance over a score of years. Virtually any one of these is the work of a lifetime.

After Aldus's death, but involving texts that doubtless had absorbed some of his interests and efforts in previous years, the Press issued

$\begin{aligned} \text { I516 } & \text { Pausanius } \\ & \text { Strabo } \\ \text { I5I8 } & \text { Biblia graeca } \\ & \text { Aeschylus } \\ \text { I525 } & \text { Galen } \\ & \text { Xenophon, Opera } \\ \text { I526 } & \text { Hippocrates. }\end{aligned}$

Aldus's successor-son, his youngest child, Paulus, would emulate his father's achievement as best he could in the decades of the middle of the sixteenth century. He would complete the Aldine Press's Greek adventure in several significant ways: Aristotle and his commentators in the folios of Themistius, Eustratius, and Philoponus, and the Greek Fathers of the Church in the guise of Gregory Nazianzen and Gregory of Nyssa. He would never reach the level of Aldus's achievement, and indeed how could he have done so? The long lists of classical authors were already substantially complete before his working life. The classical authors awaiting editorial attention and publication in print were now only a few, and for this the scholarly world had his father to thank in no small part.

There are also the ancillary works, which Aldus deliberately issued as bases for the major texts. These include dictionaries and enormous grammatical inquiries, oddities such as the Musaeus, and significantly Aldus's edition of Lascaris's Erotemata as the first book of the Press. In issuing the Lascaris to inaugurate his Greek programme, Aldus characteristically added his own study of the Greek alphabet, with explanations of the difficulties students would face in trying to learn the alphabet. In the case of certain editions of Greek authors first published by others, such as the Homer, Aldus released a new edition, but now in the revolutionary small format, thereby providing a convenient form of this literary milestone.

Aldus was well known for his own Latin grammar, and produced four editions in twenty-one years. The first was printed in 1493 by his eventual business-partner and, even more distantly, the 
man who would become his father-in-law, Andrea Torresani. The Aldine Press issued editions in I 5OI, I 508, and I 514, and again in the I 520s; his namesake grandson would reissue it more than once, late in the century. He left his Greek grammar unfinished on his death, and had left standing orders going back nearly ten years for the destruction of the manuscript. But his principal Greek editor, Marcus Musurus, completed it as an hommage to his late friend, and published it, dedicated to Jean Grolier, in the autumn following Aldus's demise.

Of all the major Greek literary authors, therefore, only Aeschylus eluded Aldus during his lifetime, as a first or revised edition, and the editio princeps of Aeschylus was published by his Torresani successors in 1518 .

This is an aside, but we should not imagine that these various Aldine editions are, on our terms, sound or even good as scholarly reproductions of what their authors originally wrote. Let us not be anachronistic. The editors of the age, including Aldus, were not the philologists of the succeeding centuries. The humanist editors of the earliest generations produced a text developed by any means commensurate with providing a readable text, customarily based upon a single, available manuscript - work, in other words, whose sentences, they hoped, parsed. They achieved this quite often through their own creative writing.

Aldus did not issue his editions uncritically; occasionally quite the contrary. The most famous instance is probably Philostratus's life of Apollonius, with allied works. The book carries three dates, March I 501, February I 502, and, finally, Aldus's concluding preface of May I504; parts of it were thus printed at different times over this three-year period. Aldus made the best of a bad job: he prefixed the text with the self-effacing words that he had originally hoped to produce something worthy of scholars; but, he confessed, this was the worst thing he could recall ever having read, and the least worthy of a learned audience.

I have been touching repeatedly on the Greek fonts, and we might note here that Aldus issued his books in a variety of typefaces and formats, all of the former notable for various reasons, and one of the latter quite revolutionary. Much has been written about the legibility and suitability of these typefaces, and there are opposing views, but the development of these faces was a deliberate matter of art imitating life.

Allowing for the physical limitations, we can say that Aldus achieved the reproduction in hard metal of the flow of the pen, or 
rather quill. He produced typefaces that were familiar to their users, by issuing books printed in fonts that mimicked the standard cursive hands, both Latin and Greek, of the humanists. He provided books that 'seemed to be written by a pen,' as the recurring phrase has it, ${ }^{26}$ and they looked as though they were printed in the scribal hands employed daily by the humanists.

The formats are both conventional and revolutionary. There were two sizes of folios, determined by the opulence of the edition, the amount of material to be gathered into a volume, and the use of standard and non-standard paper sizes. The standard size was the royal folio for very large works. The non-standard was the super-chancery folio, effectively created by Aldus for his Greek philosophical and literary editions. ${ }^{27}$ The quartos are both median and super-chancery and are essentially unremarkable. I suspect that their format was dictated in part at least by traditions involving how the marketplace expected to receive works in, for example, grammar and linguistics. They were schoolbooks, in other words, and schoolbooks have always been conservative creatures.

The octavos, beginning with the famous Virgil of April I 50I, were another matter entirely. We should consider them, both in general and in connection with the Greek titles. The first of the Greek octavos was the Sophocles of I 502, set in the smallest or fourth font. We have already considered enlarged details of the minute font created for this format, and used initially here. The edition begins with a romantic dedicatory preface to Janus Lascaris, worded in such a way as to suggest that, while the text finished printing in August I 502, the book was not proofed, completed, and issued until the following winter.

What this amounted to was that, at the same time at which he released the italic font for books in Latin and Italian, and was preparing this fourth and final Greek font in the smallest size (i.e., for this Sophocles), he started a bookmaking revolution. Aldus produced one innovation that simultaneously comprised three significant and essentially novel elements: first, he provided a straight (i.e., uncommented) classical text; second, that text was printed in a typeface that mimicked the humanist's cursive handwriting; and third, both the preceding were packaged in a small book that would fit comfortably in the hand. He did not necessarily invent each component. Fifteenth-century manuscripts of plain classical texts written in humanistic cursive may be readily found; the script itself was the current Latin standard among humanists throughout Western civilization; the small format had been used for devotional 
works for some years. But the typeface was entirely novel, and the combination of the three components was an eye-opener.

Aldus used a Greek term in naming this format an enchiridion, which means literally a small weapon like a dagger as well as a manual, and was therefore the humanist's hand-held weapon; and he spoke of publishing a large series of books that could be carried (in his phrase, libelli portatiles). ${ }^{28}$ Aldus's portable library is the harbinger of the Renaissance in printing.

He continued to experiment, both in contents and in externals. His continuing desire to make Greek accessible by presenting it in familiar texts translated from Latin into Greek was, I am convinced, the ground cause for the several religious works issued as components of grammars or as self-sufficient books. We have already encountered this practice, and it would recur until the end of his life.

Some writers suggest that Aldus issued liturgical works in Greek for the Greek émigrés, ${ }^{29}$ which I doubt highly. The Greeks, as Eastern Orthodox, would have found the Roman 'use' Aldus translated to be liturgically pointless. There were two famous instances of such liturgica in the I490s, the first a psalter and the second a Greek Hours of the Virgin. This latter book contains, in three surviving copies, ${ }^{30}$ a closely allied Brevissima introductio ad litteras graecas, which, like nothing else, speaks to me of Aldus's intentions. He wanted his fellow humanists, especially those of a pious disposition similar to his own, to learn Greek while saying their familiar canonical hours. When their Greek faltered, they had the little grammar to turn to, within the same covers. Another instance is the miniature Greek Hours of the Virgin that he published in I 505; its colophon, printed in two colors in lengthy Greek and brief Latin, states proudly that Aldus had printed the book in Venice during the reign of the Doge Leonardo Loredan.

Aldus continued, when appropriate, to issue the major Greek authors in stately folio during his publishing years in the early sixteenth century. Late in his life, in something of an autumnal period of intense labor, Aldus completed a task he had set himself nearly twenty years earlier, with the publication of the first edition of Plato in a folio that harkened back to the heady days in the 1490 s and at the turn of the century. He had mentioned at least in 1497 and in 1506 that he intended to publish an edition of Plato, and it finally appeared in 1513 , to much acclaim and success. It contains a famous preface addressed to Leo $\mathrm{X}$ in which Aldus urges him to support Greek scholarship in general, and Aldus and his pursuit of 
it in particular. The Pope would eventually respond, by establishing what is known in English as the Medicean Greek College Press, but that would occur in Rome and after Aldus's death.

We rate Aldus's achievement from the remove of five centuries, and we view his books as works of art. His books have been admired from the beginning, albeit with the rare grumble on the part of the abstemious that the margins were sometimes too ample. But activity within the Press did not run smoothly on many occasions. There were larger major disruptions caused by outside events such as warfare that need not detain us. There were major internal disruptions caused by much more basic factors. Let us recall that, initially, Aldus was the conceptualist, Barbarigo the silent financial backer, and Andrea Torresani the technical and executive manager.

We can judge from the sporadic appearance of the Greek books that the work ebbed and flowed, with many titles coming out at some periods and virtually none at others. One major problem was money. The books in Greek were priced at at least twice but often thrice the minimal fixed prices for the Latin and Italian books. There was clearly sales resistance, and we have letters mentioning the problem in the guise of: what I have to pay for one of Aldus's Greek books would buy me three or more Latin books. There is a record of another sort, from Johann Cuno, the German Dominican in Venice who sometimes served as Willibald Pirckheimer's agent for purchasing books to be shipped to Nuremberg. He mentions in I 505 that Andrea Torresani has called a halt to the publication of Greek books: they are too expensive to produce and the sales did not justify the continuation. Torresani is traditionally portrayed as stingy, mean, and crass. This may or may not be true, and it is too sharp a portrait from a very partisan source (Erasmus) to earn our credence. But the expense - perhaps undue expense - of producing the Aldine Greeks can be judged from what we know of the books themselves and the documentary evidence.

Beyond this, there is the question of the market. The books were intended to be true Greek books that would look familiar to anyone accustomed to reading Greek, either in manuscript or in type. (There is a strikingly slavish similarity between the appearance of the page of type in Aldus's folios, both typographic mise-en-page and decorative elements, and the physical arrangement of the known surviving setting-copy manuscripts. ${ }^{31}$ Allowing both for the Greek émigré scholars and for the non-Greek humanists, however, there was still a very limited number of people requiring copies of literary and grammatical works in Greek. 
Speaking of authentically Greek elements in the composition of the books, in their internal structure, leads me to note briefly the external Greek structure. Quite often /to judge from the number of survivors|, Aldines containing Greek texts were garbed in Greek bindings..$^{32}$ These take the guise, historically, either of authentic Greek bindings, whether made by Greek expatriate bookbinders or by Italian bookbinders reproducing the work taught them by Greek masters, or of Greek-style bindings created by Western practitioners emulating Greek prototypes. The distinguishing hallmarks are a bookblock flush with the edges of the boards, extended endbands laced directly into the grooved edges of the boards, and interlaced thongs fastening onto pins to secure the book in a closed position. The skill will be found outside Italy, in France, by mid-century. As in their closely allied cuisines, the Italians and French enjoyed vigorous mutual growth in their book arts. By mid-century, it was possible for French master bookbinders to achieve truly Greek workmanship, if with their own vernacular highlights, in producing the binding alla greca or à la grec. Greek and Greek-style bindings played a large role in the wholesale rebinding of the Fontainebleau library undertaken for Henri II. At about the same time, French master binders adapted to standard Western bindings the à la grec element of the flat spine.

How to assess Aldus, and scholarship, and Greek learning? In his last quarter-century of life, the publishing years in Venice, not even allowing for the four years of interruptions, he was responsible for a vast number of editions of the Greek and Latin classics, with a diverse admixture of other works, issued in typefaces that appealed to, indeed derived from, the humanists. He made literature accessible. We need not struggle unduly with our own evaluation of Aldus's achievement: it would be pretentious of us to do so, and many of us already spend valuable time keeping his memory green in one way or another. Aldus has never been without his supporters and venerators, and they have always far outnumbered his detractors. They exist today - witness this special issue - and they existed from the beginning. Contemporary appraisals of Aldus's work have passed into our common repertory.

Erasmus of Rotterdam was staying in Bologna with a member of the Bombace family, friends of Aldus's, in the early autumn of 1507. Aldus at this stage had been away from publishing, during the first of his two long interruptions, for more than a year-and-a-half. Erasmus proved to be the goad that got him back to work from a long, well-deserved respite. He wrote to Aldus proposing that Aldus 
issue a new edition of Erasmus's translations of Euripides's Hecuba and Iphigenia in Aulis. More specifically, he asked that the book be composed in the most elegant small italic typeface. He arrived at the new location of the Press at the end of the year, and stayed, working at Aldus's elbow, until September 1508. The ideal and detached wandering scholar, Erasmus seems to have become worn out by watching Aldus's quality and quantity of work. He also produced a huge edition of his Adagia and he developed boundless respect for Aldus as scholar and printer.

In his Utopia, of 1516, Thomas More (through Erasmus and Linacre a distant member of Aldus's extended circle) gave the Utopians a select library of classical authors. They included Plato, Aristotle, Theophrastus, Lascaris, Hesychius, Dioscorides, Plutarch, Lucian, Aristophanes, Homer, Euripides, Sophocles, Thucydides, Herodotus, and Herodian. The editions, one quickly realizes, were all Aldines.

The first major bibliography of bibliographies is the work of Conrad Gesner (I 5 I 6-1 565), of Zürich, the Bibliotheca universalis, of 1548 . The very rare second volume of this work, Gesner's Pandectarum libri, appeared in the same year. It is the general subject index to his prior volume, in the form of a score of books on a wide variety of topics and fields, each dedicated to a famous printer. Book II is on Geography, and Gesner dedicated it to Paulus Manutius, son of Aldus. He provides a catalogue of the publications of the Aldine Press going back to the beginnings, and he praises Aldus's achievements at length. He tells Paulus that 'Greek books before your father were either non-existent, unless I am wrong, or very few. Neither were they printed by the method discovered by my fellow-Germans; we owe no less to Aldus for his accomplishment in perfecting and completing the craft, however, than to the discovery itself.' 33

Mutianus Rufus had been a student in Italy in his youth. In the summer of 15 Io he was a canon in Gotha, living in his tiny house named 'Beata tranquillitas,' which was decorated to his taste and where he continued his literary studies. He wrote to his protégé Henricus Urbanus, with whom he maintained a vigorous correspondence, and whose name is familiar to Reformation scholars. Mutianus bemoaned the outside world. The worst thing was the never-ending round of Franco-Venetian warfare, which had closed the Alpine passes to trade. And the consummate outrage was the development from this state of affairs that learning was bereft of Aldus's help. Mutianus's equation of Aldus with scholarship is all 
the more ironic to us, because we know that at this time the War of the League of Cambrai had driven Aldus to refuge in Ferrara, the Aldine Press was closed indefinitely, and Aldus does not appear to have been entertaining strong notions of returning to the world of publishing at Venice.

Thomas Anshelm, whose accomplishments in Tübingen and Hagenau were considerable, functioned for all practical purposes as printer by appointment to Johann Reuchlin and his circle, leaders in the Northern Renaissance. He took his lead from Reuchlin, followed Reuchlin as the scholar moved to teach in different towns, issued Reuchlin's editions, and reprinted the books Reuchlin supplied. A number of Anshelm's titles were set from books that Reuchlin had bought from Aldus - the works are mentioned in detail in their surviving correspondence - and some of them were edited by Melanchthon, who was Reuchlin's grandnephew and had been trained by him. (I am constantly struck by the human scale of the world in which these people worked, and how well the book market functioned, despite the distances involved and the physical obstacles of the times.)

Anshelm published in 1517 the first edition of a treatise on the various merits of wine and water, or of drunkenness and sobriety, by a Hungarian humanist, Valentinus Cybeleius, a canon at Alba regalis (in the vernacular Székesfehérvár, once the royal capital; it lies southwest of Budapest, toward Lake Balaton, the Hungarian wine region). He has many anecdotes on drunkenness and sobriety, and his attributions of sources include Aldus. ${ }^{34}$ This may serve as an odd reminder that there were strong direct ties between Aldus and the humanists in central Europe, particularly Poland and Hungary.

What is easily shown is that, for his contemporaries across the landscape of Europe, from the distant British Isles /which even Aldus described as cut off from the Continent and by implication from civilization) to the plains of east-central Europe, Aldus was classical learning and its diffusion.

Aldine scholarship is scarcely static, though Aldus and Aldine studies have widely been viewed for years by the uninitiated as an excessively tilled field: there's nothing new to discover. ${ }^{35}$ One would certainly think that the Aldine Aristotle has been investigated to within an inch of its life. But our colleagues at UCLA, and possibly elsewhere, are working on a problem recently noted by bibliographers.

The two-part fourth volume of Aristotle, that containing Theophrastus, includes two major cruces. (And bear in mind, by the bye, 
that Aldus complained of being able to find only one manuscript of Theophrastus in all of Italy.) Several leaves in signature y/chi reflect major difficulties that were perceived as such and dealt with in a practical, physical way. On one leaf, corrected lines are present in a pasted-on cancel slip, obscuring what had previously been set; on another, space for seventeen lines of type is left for a lacuna. In the traditions of his day, Aldus expected readers to discover ultimately what was missing in his setting-copy manuscript, and eventually to supply this want with pen and ink.

No one in the academic world apparently had adverted to this problem until the spring of 1995 , when it was briefly mentioned in an auction catalogue. ${ }^{36}$ It is just beginning to be given professional treatment in a major scholarly research environment. The immediate questions are obvious enough, and they may lead to even more complex questions. Why did Aldus leave this lacuna, and why did he cancel some of what he had already accomplished? What does this say about the setting copy and the archetype? Is there more of this going on than we realize, and even the instances themselves remain to be noticed?

Following Aldus's death, and even from the beginning of the long, gradual diminution of his firm as a major scholarly publishing house, Venice itself began a permanent recession as a center of scholarship and of publishing. The printing locales that dominated over the following decades took the focus of publishing to Switzerland, France, and the Low Countries.

I have already alluded to the diminished work awaiting Aldus's successor-son a generation later, and how could matters be otherwise? The Froben and Estienne firms took the lead, and the PlantinMoretus enterprise would be succeeded by the Elzevirs. These later firms served very well the needs of the great philologists who arose in the later sixteenth and flourished across the seventeenth century. The firm foundation on which all of them would build can be found in the granite hewed by Aldus in a mere score of years. 


\section{RÉSUME}

L'étude d'Aldus Manutius doit se développer autour de deux grandes questions importantes, la première étant la Renaissance et son principe directeur l'Humanisme, et la seconde l'origine de l'imprimerie utilisant des caractères mobiles dans l'Europe de l'ouest et sa migration par les Alpes jusqu'en Italie et par la suite en particulier jusqu'à Venise. Notre examen des succès et déboires d'Aldus doit prendre en considération l'Italie, la Renaissance, l'Humanisme et le renouveau des études classiques dans l'Europe de l'ouest. Cet exposé examine plus particulièrement la contribution d'Aldus à l'impression des textes grecs dans leur langue originale.

\section{NOTES}

I This article reproduces most of the text of my lecture at McGill University, rewritten to remove the elements of oral delivery and the more general background material; I have added notes and additional comments. Its length notwithstanding, this paper constitutes a cursory treatment of some aspects, and I skim many a surface. The documentary citations for much of what follows may be found in my New Aldine Studies (San Francisco: Rosenthal, 1988) and In Praise of Aldus Manutius (New York: PML; Los Angeles: UCLA, 1995); cited hereafter as Fletcher, NAs and Fletcher, In Praise.

2 Having written recently at some length on this topic, I shall confine myself here to a summary description, and refer the interested reader to my 'The Ideal of the Humanist Scholar-Printer: Aldus in Venice,' Printing History 30 /Vol. I 5 No. 2, 1993|: 3-12. A very short statement is in Fletcher, In Praise, 19.

3 J.H. Plumb, The Italian Renaissance (Boston: Houghton Mifflin, 1987) is a convenient and concise source, originally published in $196 \mathrm{I}$, which includes many specialized chapters by numerous learned contributors.

4 L.D. Reynolds and N.G. Wilson, Scribes and Scholars, 2 d ed. (Oxford: Clarendon Press, 1974), 108; there is now a third edition.

5 The current scholarly discussion of this entire phenomenon is the catalogue of the major exhibition held in Venice at the Biblioteca Marciana in the spring of 1994. See Gianfranco Fiaccadori, ed., Bessarione e l'umanesimo (Naples: Vivarium, 1994).

6 Martin Lowry, The World of Aldus Manutius (Oxford: Blackwell; Ithaca: Cornell University Press, 1979|, esp. pp. 229-32, faults Aldus for not using the Bessarion manuscripts in his editorial work. Professor Lowry notes that Bessarion intended his gift to be a scholarly resource, open to all who wished to use it, but that the Venetian authorities caused the manuscripts to be closed off, without drawing 
the necessary conclusion, for Aldus or any other contemporary scholar. Contrast this with the concise statement in Reynolds \& Wilson, Scribes and Scholars, that the entire Marciana was 'very badly housed and difficult of access for more than half a century after Bessarion's donation' (p. 240; citing, moreover, a study dating from 1868 ).

7 At the risk of trivializing a massive subject, I shall take the convenient path of suggesting, as a brief portrayal of a complex topic, my own Gutenberg and the Genesis of Printing (New York: PML, 1993).

8 This is treated at some length in Fletcher, In Praise, especially 2-7, 12-16.

9 Edwin Hall, Sweynheym \& Pannartz and the Origins of Printing in Italy ([McMinnville]: Bird \& Bull Press for Pirages, 199I) is an excellent and current source.

Io Martin Lowry, Nicholas Jenson and the Rise of Venetian Publishing in Renaissance Europe (Oxford: Blackwell, 1991). The traditional story about Jenson's initiation into printing goes at least as far back as Jean Grolier himself, and identifies Jenson with a certain cutter of dies (tailleur) at the Paris mint who was dispatched in $\mathbf{I} 458$ by his sovereign, Charles vir, to investigate rumours of a marvelous new invention for printing books, in the city of Mainz. The traveler returned to find Louis XI on the throne, suspicious of all his late father's emissaries.

I I Most recently illustrated in J.J.G. Alexander, ed., The Painted Page: Italian Renaissance Book Illumination (London: Royal Academy; New York: PML, 1995l, no. ror.

I2 For illustrated examples of several of the numerous surviving Venetian incunables illuminated for presentation to or on commission for Ugelheimer, see Alexander, Painted Page, nos. 96-ror.

I3 For a fascinating proposal about Cusanus's role in bringing Sweynheym and Pannartz to Italy, see Johannes Röll, 'A Crayfish in Subiaco: A Hint of Nicholas of Cusa's Involvement in Early Printing?,' The Library, 6th series, 16, 2 (June 1994): 135-40. Moreover, in commenting on Gutenberg and his 42-line Bible and hypothesizing a major role for Nicholas of Cusa, Nicolas Barker points out that Cusanus's 'interest in printing is attested by his chaplain, Gianandrea de' Bussi, publicist of the first printers in Italy, Sweynheym and Pannartz.' (Bussi functioned, particularly in Rome, as the house editor of the Sweynheym and Pannartz venture.) See Nicolas Barker, Aldus Manutius: Mercantile Empire of the Intellect, University Research Library Occasional Papers 3 (Los Angeles: UCLA, 1989), 13.

I4 William H. Ingram, 'The Ligatures of Early Printed Greek,' Greek, Roman, and Byzantine Studies 7, 4 (1966): 37 I-89. The author remarks (at p. 373), quite sensibly, that 'A Greek type face is, after all, designed primarily to be easily readable by persons, contemporaries of the printer and type designer, who read Greek; assuming that they publish the same works, a publisher whose Greek books are difficult to read will not sell so many books as one whose type is familiar and easily legible. All other considerations, even aesthetic ones, must eventually yield to such a basic economic fact.' 
I5 Robert Proctor, The Printing of Greek in the Fifteenth Century ([London]: Oxford University Press for the Bibliographical Society, 1900), 75.

I6 Nicolas Barker, Aldus Manutius and the Development of Greek Script 4 Type in the Fifteenth Century, $2 \mathrm{~d}$ ed. (New York: Fordham University Press, 1992), 37.

I7 In an unpublished lecture, 'Aldus Manutius and the Aldine Press,' delivered at The Frick Collection, 23 January 1954. The manuscript is on file in the Department of Printed Books, PML.

I 8 In a conversation with me.

I9 Martin Davies, Aldus Manutius, Printer and Publisher of Renaissance Venice (London: British Library, 1995), 14.

20 Barker, Aldus and Greek, $128-3 \mathrm{I}$.

2I Ingram, 'Ligatures,' states (p. 374) that Aldus's 'type face carried the field precisely because of its easy readability; and instructed by his success, other early printers of Greek gradually abandoned their experiments with type faces of a more formal stature.' And this in a sense despite the fact: 'To our modern eyes the older book-hand style may seem clearer than Aldus' cursive type, and we may privately wonder at the exotic literary skills of a public which preferred the Aldine fount to its competitors on the grounds of ease in reading; but such was indeed the case, and Aldus became further emboldened with each new success. Individual letters were made for him in increasing varieties of forms, and contractions were devised for newer and larger combinations of letters.'

22 Barker, Aldus and Greek, 83-4, plates 34, 37, and 38.

23 Ibid., 88, pls. $4 \mathrm{I}-3$. Note especially the microscopically ingenious way in which the originally ligatured sort gamma-chi $(\mathrm{pl} .43)$ is cut to permit clearer readability on the printed page.

24 'Prego pero Dio, chel me dia gratia che possa io fare tale officio, et mandare al executione la Academia, che desidero de fare.' The full text is edited in Fletcher, NAS, 166-9; the citation is at p. 168.

25 It will be found conveniently tabulated in J.E. Sandys, $A$ History of Classical Scholarship, 3 vols. (Cambridge: Cambridge University Press, 1906-1908), II: I04. See also the tables in Lowry, The World of Aldus Manutius, I I 2-I 3, I 44-5, 150-1, 162-3; these tables are also valuable for their statistics on the numbers of leaves printed, a sure gauge of the volume of work achieved.

26 'Ut conscripti calamo videantur.' The phrase occurs, for instance, in the dogal decree of 14 November I 502, the edited text of which may be found in Fletcher, NAS, I46-7; the citation, at p. 146.

27 This is the conventional (for him, that is) size of all Aldus's Greek folios, and it produces an elongated page, taller than the standard or chancery folio; the term is the invention of Paul Needham. Discussion of this paper size has begun to be published in, e.g., Sotheby's catalogues carrying Dr. Needham's descriptions of Aldine incunables, as well as in his 'Aldus Manutius's Paper Stocks: The Evidence of Two Uncut Books,' Princeton University Library Gazette 55, 2 (Winter 1994): 287-307. The only use of this format prior to Aldus's was in early printing at Augsburg, in the I470s; a connection, if any, has not yet emerged. 
28 In his 22 June 1503 catalogue, 4; facs. in Carlo Dionisotti, ed., Aldo Manuzio editore, 2 vols. (Milan: Il Polifilo, 1975), facing I, 75. Through carelessness or some other error, I originally cited the phrase as libri portatiles, and I note guiltily that the erroneous form libri has been repeated by others.

29 E.g., Davies, Aldus Manutius, 28.

30 Two of them are in the PML collections; the third is in Paris, according to information given to me by Dr. Davies.

3I Several reproductions from these setting manuscripts, exhibited in the spring of 1978 at the Herzog August Bibliothek, Wolfenbüttel, may be found in the catalogue by Johanna Harlfinger, Joseph A.M. Sonderkamp, and Martin Sicherl, Griechische Handschriften und Aldinen (Wolfenbüttel: HAB, 1978).

32 Several contemporary Greek bindings are discussed and reproduced in color in the wide-ranging article by Gabriele Mazzucco, 'Legature rinascimentali di edizioni di Aldo Manuzio' in Suzy Marcon and Marino Zorzi, eds., Aldo Manuzio e l'ambiente veneziano, I494-IS IS (Venice: Cardo Editore, I994), 135-79.

33 'Exemplaria Graeca ante patrem tuum aut nulla, ni fallor, aut pauca, nec ea industria typis publicata sunt. Prima huius artis inuentio Germaniae nostrae adscribitur; sed non minor uirus est, tueri \& perficere rem inuentam, quod Aldo debemus, quam inuenire.' Conrad Gesner, Pandectarum sive partitionum universalium . . libri xxi (Zürich: Christoph Froschauer, 1548), fol. $107^{\mathrm{r}}$.

34 Valentinus Cybeleius, Opusculum De laudibus et vituperio vini et aquae (Hagenau: Thomas Anshelm, 1517 ), fol. $\mathrm{A}_{3}{ }^{\mathrm{r}}$. Recorded in Schreiber cat. 24 [1990], no. 20.

35 I mention this, I confess, out of at least a partial effort at self-defense, having once been turned down on precisely these grounds when I sought support for part of the research that eventually led to NAs.

36 The Library of the late M[ax]. F[avia]. d[el]. C[ore]., Francesco Radaeli, expert (Lugano: Guido Craveri, I9 June 1995), lot II. Originally the Johann Jakob Breitinger (Zürich: 1575-I645) copy, it had just previously belonged to John A. Spranger (1 889-1968). At the time of the Spranger sale (Sotheby's London, 2 I November I989, lot I I |, one lacuna was listed in Sotheby's description, though not noted by bibliographers. At this writing, the set is the property of Wolfgang J. Kaiser, of Frankfurt am Main. 
